\title{
Daily Bread: Women's Self-Help Microfinance and the Social Meanings of Money
}

\section{Abstract}

In this article we explore the impacts and implications of 'Rojiroti', a women's self-help group (SHG) microfinance scheme operating in poor communities in Bihar, India. We focus particularly on how improvements found in women's circumstances and in children's health might result from Rojiroti SHG membership. Through data from five focus groups and 19 individual interviews with women in communities where Rojiroti operates, we discover how the scheme is regarded and how it affects women's management of household budgets. Moreover, we explore the relational aspects of SHG microfinance and the ways that it can alter family and social dynamics. Drawing on notions of 'earmarked' money (Zelizer, 1997) and 'safeguarded' money (Wilkis, 2017), we argue that the money itself has meaning and non-pecuniary value in the form of other currencies including power and agency, which can lead to improved wellbeing and health of families.

\section{Introduction}

Rojiroti (meaning 'livelihood' or 'daily bread' in Hindi) is a women's microfinance scheme operating in 'tolas' (hamlets, often named after their geographical location and caste connections) in Bihar, in India's East Zone. Rojiroti is NGO-led, by the Centre for Promoting Sustainable Livelihood (CPSL) and is only available to women. The tolas, which are amongst the poorest in India, are largely inhabited by 'Scheduled Castes', which are sub-communities in the Hindu caste system who have historically faced oppression, denigration and social isolation in India on account of their perceived 'low status' (Gopinath, 2018). The target 
communities are predominantly patriarchal with high rates of illiteracy and intimate partner violence (IPV).

The Rojiroti scheme requires members to form self-help groups (SHGs), comprising a minimum of ten members including a lead member. Key defining features of Rojiroti are the comparatively small amounts borrowed and the flexibility around borrowing purposes and repayment schedules ${ }^{1}$. There are no restrictions on reasons for borrowing, provided the SHG group is in general agreement. One important difference between Rojiroti and most other microfinance schemes is that because group leaders mostly belong to the communities they serve, they share a similar socioeconomic background with SHG members, which helps foster non-hierarchical group relations. Crucially, accessing Rojiroti loans helps women bypass local money lenders (who charge much higher interest) and avoid emergency sales of their property (at vastly deflated prices).

Recent quantitative research by Ojha et al (2019) uncovered links between Rojiroti microfinance and improved children's health in the tolas. The research found that Rojiroti membership often led to improvements in the nutrition and growth rates of young children. The substantive links between women participating in microfinance and improvement in children's nutrition are unclear and this article draws from subsequent qualitative research which explores the effects of Rojiroti loans on families, particularly on women and children's welfare. The project forms part of broader ongoing research into microfinance and women's and children's health in Bihar. It is funded under the AHRC-MRC Global Public Health Partnership scheme. The partnership includes:

- Rojiroti (UK-based charity);

- CPSL;

- School of Sociology \& Social Policy and the School of Medicine (both at the University of Nottingham, UK);

- A.N. Sinha Institute of Social Studies (ANSISS) in Patna, Bihar.

\footnotetext{
${ }^{1}$ The mean amount of Rojiroti loans is USD 42 while the average for microfinance in India is USD 367 (SIDBI, 2019). However, typical (median) Rojiroti loans are much smaller.
} 


\section{Rojiroti and Children's Nutrition}

As noted above, the qualitative questions underpinning this research stem from findings from prior medical research conducted by the British and Indian project partners in Bihar. This involved a cluster randomised controlled trial which investigated the effects of Rojiroti microfinance loans on child nutrition. The nutritional states of children under five years were measured in the intervention (Rojiroti) tolas and control groups after a period of 18 months. Data on 56 tolas (1326 women \& 2064 children) were analysed and the results show that, after 18 months of Rojiroti microfinance, children in the intervention tolas were significantly better nourished than those in control tolas, for each outcome measured (Ojha et al, 2019).

Aside from yielding vital original nutritional data on the impacts that microfinance loans can have on the health of families living in extreme poverty, the research also opened important under-researched questions about how wealth is a determinant of health in this context, especially since the sums were comparatively modest. There is a suggestion that, in relation to the flexible nature of the Rojiroti scheme and its self-help method of intervention, the money itself has implications and value in the form of other currencies, e.g. power, control, agency, independence, mobility and so on. These are nuanced and often intangible factors that require in-depth, face-to-face qualitative exploration.

\section{Microfinance \& Poverty}

Though microfinance is a controversial and contentiously debated intervention, in lowermiddle-income countries like India where many endure conditions of long-term poverty and marginalisation and do not have access to credit through formal banking services, it can arguably play a vital role in poverty alleviation (Kumar, Chauhan, \& Kumar 2015; Sinha \& Agarwal 2010). Self-help group (SHG) microfinance in particular is viewed as enabling poor 
households to save and manage money, which can buffer them from unexpected financial crisis (Verma \& Aggarwal 2014). Research by Yaron et al $(2018 ; 2019)$ on the effects of microfinance on marginalised communities in India drew on the Rojiroti scheme as a SHG case study. The research found that within a short period of time as members, women were demonstrating significantly increased participation, particularly in the organisation of household finances. The authors also report improvements in capacity and decision-making and a fall in reports of IPV among members (Author et al 2019). Elsewhere, it is argued that access to microfinance can improve women's reproductive health and capacity for property ownership and decision-making, which can lessen their vulnerability to IPV (Hashemi et al. 1996; Pitt \& Khandker 1996)

Other studies, however, have presented counter arguments about the effects of microfinance on women living in largely patriarchal settings, and there is little consensus on what constitutes empowerment (Goetz and Gupta 1996; Guerin, Kumar and Agier, 2013; Hunt and Kasynathan 2001). Shettar (2015) argues that women's empowerment in India is especially complex and contingent on many intersecting factors including geographical location (urban/rural), educational status, social status (caste and class) and age, and that there is significant disjuncture between policy advancements, including microfinance SHGs, and actual practice at the community level. Further, Lahiri-Dutt and Samanta (2006) have questioned the tendency to view SHG 'networking' as inherently positive for women, because such a view overlooks the disparities and hierarchies that divide women along lines of class, caste, ethnicity and religion. Guérin (2011) argues that SHG microfinance can actually deepen divisions between group leaders and other group members.

Broader critiques of microfinance question claims that it reaches the 'poorest of the poor' and the general acceptance that loans are predominantly taken for investment in microenterprises that lead to empowerment for women (Hulme and Arun 2011). Studies have 
presented contradictory findings in this regard; some have shown that microenterprise priorities are not realised as borrowers instead buy food and other immediate commodities (Karlan and Zinman 2010), whereas others illustrate, for example in the case of urban microcredit in Hyderabad, India, that whilst no increase in new enterprises occurred, existing businesses were invested in and borrowers mostly resisted 'temptation goods' in favour of more durable necessities (Banerjee et al 2013). In Lamia Karim's ground-breaking ethnography of women's microfinance in Bangladesh, she argues that the main purpose of microfinance institutions is to generate profit and status for those who run them, while the women who are the supposed beneficiaries experience unmanageable pressures on their time and resources. Rather than helping women, microfinance has arguably reinforced the patriarchal social structures in Bangladesh, leaving women with greater obligations than before whilst failing to make a meaningful dent in poverty (Karim, 2011). Others have also suggested that microfinance exacerbates inequalities among women (Rankin, 2002; Guérin \& Palier, 2005; Pattenden, 2010) and creates new forms of indebtedness and dispossession (Mader, 2015).

Critics have questioned the neoliberal underpinnings of the assumed connections between socioeconomic advancement and finance, and the 'mobilising narratives' that tether women's participation to formal markets and women's 'empowerment' to microfinance (Elyachar, 2012). Mader contends that in certain narratives, microfinance is 'understood as a force for liberating women from traditional gender identities, allowing innate entrepreneurs to prosper, or helping poor people manage their difficult economic lives better - a narrative which has finance granting the "power to" develop' (Mader, 2015: 6).

On the other hand, links between women's empowerment and self-help groups of various kinds aside from microfinance have been made. Writing on women's groups in India, Sultana concludes that women's group formation can generate knowledge exchange, 
consciousness-raising and group mobilisation, which together can 'create an alternative to women's traditional condition and contribute to women's ability to speak out and earn a relatively higher status in the family and in the village' (Sultana 1998 cited in Vijayanthi 2003:273). Similarly, Vijayanthi found that involvement in collective credit management and savings systems among women in a sanitation SHG brought about positive changes in group cohesion and encouraged mutual dependence among members. Vijayanthi argues that this constitutes empowerment at both collective and individual levels for marginalised women (Vijayanthi, 2003).

The lack of consensus in debates on microfinance (both in empirical research such as the work cited above, and in larger economic and theoretical debates that are beyond the scope of this article) suggests that it is highly variable and context-specific, and that the social dynamics of different schemes affect outcomes. The nuances of SHG members' relationships with one another, as well as with the socially and culturally symbolic meanings of money require further interrogation.

\section{Microfinance \& the Meanings of Money}

Because it explores microfinance as a catalyst in family health, this research is concerned with the changing relationships the SHG members have with money as a result of taking on a Rojiroti loan. Since the non-material currencies of sums as small as a few US dollars appear high when considering how far the money stretches in terms of improved children's health, the intangible currencies seem significant. We develop our analysis, therefore, through theoretical frameworks of the meanings of money.

We draw on Viviana Zelizer's vastly influential work on the social meanings of money, in which she argues that money is pluralistic and qualitatively differentiated (Zelizer, 1997; 2012). In critique of dominant economic understandings of money as a singular, 
neutral market unit, sharply divided and separate from nonpecuniary values, Zelizer argues that money does not exist as a uniform, homogenous medium. Rather, there are 'multiple monies', and 'people earmark different currencies for many or perhaps all types of social interactions, much as they create distinctive languages for different social contexts' (Zelizer, 1997:18). Even very small sums of money can become imbued with 'fantastic properties that transcend the definiteness of numbers' (Zelizer, 1989: 352).

Zelizer examines how the source of money affects how it is valued and spent. Using the example of money that circulates in families, she discusses how household power relations affect the social meaning of household money, suggesting that 'the battle over the purse strings [is] regulated by notions of family life and by the gender and class of its participants' (Zelizer, 1989: 353). Tracing the history of 'housekeeping allowances' or 'pin money'- that is to say money handed over to women directly from male breadwinners' pay packets-Zelizer suggests that historically money is a major source of dispute and conflict within households, and that 'earmarking' of different types and meanings of money denotes and maintains the social relations underpinning different kinds of monetary exchange. Zelizer argues that a variety of earmarking practices are articulated in conjunction with gender roles and family dynamics, and that when money is earmarked, its meaning is contingent on who generated it and where it originated (Zelizer, 1989; 2012).

In a similar vein, Ariel Wilkis, in The Moral Power of Money (2017), argues that the hierarchical order of poor families is rooted in money, which represents a central mediator of power and status relationships. Wilkis, like Zelizer, explores different kinds of money and their relative social meanings. He suggests that 'the family order is yet another realm where money helps construct power relations among family members of different genders and different generations' (Wilkis, 2017: 164). Wilkis presents the notion of 'safeguarded money', which is money saved or set aside for specific purposes. The deliberate act of putting 
money aside is integral to the 'set of feelings and perspectives of safeguarded money', which is regarded more highly than other types of money (Wilkis, 2017: 139). This connects to debates on the various moral dimensions of debts, which are themselves differentiated on the perceptions of lenders and how morally obliged debtors feel to repay them (Poletta and Tufail, 2012).

Understanding the meanings of money and how those meanings shape women's status and standing within households is useful to considering the impacts and implications of SGH microfinance. Women's relationships with Rojiroti, as oppose to other forms of income, such as housekeeping money or private credit, are unique in terms of the discretion and control SHG members have over how it is earmarked and safeguarded, the collective duty borrowers feel to honour repayments and the changes to household relations that might unfold as a result.

\section{Methods, Ethics and Power}

Over a period of three weeks during the winter of 2018/9, the research team carried out exploratory/pilot fieldwork in the tolas previously studied by Author et al. (2019) in Bihar. The fieldwork team included two co-investigators, Esther Bott and Shalini Ojha, and Sunita Mini, a junior researcher and $\mathrm{PhD}$ candidate at A.N. Sinha Institute of Social Studies (ANSISS) in Patna, Bihar. Bott is a white British woman with no Hindi or local minority language skills. Her presence on the project and in the field solely rested on her expertise in qualitative social research, including extensive experience in interviewing women in the Global South on potentially sensitive subjects. Ojha is a paediatrician with expertise in newborn health and health research. Originally from Bihar, Ojha is a first-generation migrant to Britain. Her socio-economic and caste identity from the local perspective is upper caste and upper educated class. She is conversant in Hindi, including the local dialects of Magahi and Bhojpuri. Mini has experience of interviewing women from Scheduled Castes and excellent language/dialect skills. She was employed as Research Assistant (RA) to conduct interviews in Hindi and local dialects and translate and transcribe audio recordings thereof. 
She worked throughout under the guidance of Bott and, for the first six days in the field, Ojha. Mini and Bott carried out all interviews and held focus group sessions. Other coinvestigators on the project include Dr Rajeev K Kumar, Assistant Professor in Sociology and Social Anthropology at ANSISS and Mr Sunil Choudhary, Director of CPSL.

Participants were recruited directly from established SHGs. Choudhary was responsible for arranging initial access. He outlined the research to Rojiroti members and invited participation through targeted sampling prior to the arrival of the research team in Bihar. Choudhary has well established links with women from the target communities and was successful in arranging five group interviews in advance, from which we were able to recruit 19 individual interviewees. Whilst this route to access was convenient and practical, it presented ethical dilemmas and a potentially skewed sample, which we discuss further below.

Given high illiteracy rates among participants, verbal consent for interviews and focus groups was obtained. Detailed information from a participant information sheet and consent form was conveyed and participants were asked if they agreed to participate on those terms. Their verbal responses were audio recorded. We also asked participants to audibly confirm they were aged 16 or over. Participants were assured full anonymity (as individuals and in terms of their connection to loan groups and tolas) and the opportunity to withdraw from the research at any point, including withdrawing data already recorded. Interview and focus group data were also electronically recorded and transcribed using pseudonyms. The recordings were stored in password-encrypted files in password-locked devices. In compliance with University of Nottingham policy and UK data protection and privacy laws (GDPR) all data files are now stored only in an encrypted personal account in the University of Nottingham OneDrive storage facility. 


\section{Focus Groups and Individual Interviews}

Five focus groups of between six and twelve women were held, from which we recruited 19 individual interviewees across all four sample groups (see Table 1 below). The purpose of the focus groups was to establish rapport and trust between researchers and participants and to begin to explore the research questions and themes. Given the tight schedule and the exploratory nature of the fieldwork, focus groups were a useful way to gather the opinions of multiple individuals at once. As Cyr (2016) notes, focus groups can reveal group-level consensus/disagreement on phenomena and can help in the development of research design and questions. In the case of this research, the focus groups elicited themes that were explored further in individual interviews, though focus group dynamics were problematic in other ways (as explained below). With Rojiroti members, in both focus groups and subsequently in more detail and privacy in individual interviews, we asked about their experiences of SHG membership, with a particular focus on the changes to family life it brought about. We enquired about how spending decisions were made and the main benefits and drawbacks of Rojiroti microfinance. In discussions with participants who had chosen not to join Rojiroti we asked about the factors influencing their decision and how their households were funded. Finally, with women from communities without access to Rojiroti, we asked if and why they wanted Rojiroti microfinance and enquired about possible alternative sources of funding. 
1: Long-term members (more than 2 years

2: Recent members (up to 2 years)

3: Non-members (Rojiroti available)

4: Non-members (Rojiroti not available)

TOTAL

\begin{tabular}{|cc|}
\hline 2 & 6 \\
1 & 5 \\
1 & 3 \\
1 & 5 \\
5 & 19
\end{tabular}

Table 1 showing sample groups and frequency of focus groups and interviews

Focus groups and interviews were semi-structured, carried out using an interview guide to provide structure and to assist the RA to cover necessary thematic areas, but questions were open-ended to allow narratives to freely emerge. There were practical issues with both focus groups and interviews, particularly in terms of creating quiet spaces where women could talk openly. Two focus groups were held indoors - once in the CPSL field office and one in a classroom. The remaining three occurred outdoors in makeshift space consisting of rugs or plastic sheeting placed on the floor upon which we sat. Our presence in the remote rural tolas generated curiosity and a degree of excitement, with many residents coming out of their homes to regard or greet us. All five focus groups were, to varying degrees, chaotic, being 'gate-crashed' by curious relatives, late-comers, children and sometimes husbands wishing to eavesdrop. This created ethical dilemmas that are discussed below, but also practically speaking it caused distraction and disruption to the flow of conversation for participants. Many women were too shy or nervous to join the groups immediately and took their time to adjust to our presence. Each late arrival to focus groups required us to read the participant information and seek verbal consent. Further, perhaps unfamiliar with the concept of social research and methods, the women tended to form break-away conversations which resulted in many people talking at once. Whilst this level of engagement and free-flowing debate was encouraging, it did also make following the discussion and deciphering audio recordings difficult and we acknowledge some loss of data as a result. Individual interviews were mostly 
conducted in private homes but gate-crashing by curious family members still occurred. As we were uncomfortable about asking women to leave their own —or their relatives' — homes, we devised a strategy where Ojha waited just outside the doorway to gently intercept and engage potential interlopers in conversation. This also had the benefit of improving trust and rapport, as Ojha was able to provide answers to questions about us and our research.

\section{Feminist Dilemmas}

Since its primary concern is to contribute qualitative analysis to help understand the everyday lives of marginalised women in Bihar, the research adopted a feminist methodological approach, which stresses the importance of bringing women's voices and personal experiences to the fore. Harding (1987) argues that feminists have a responsibility to air and validate the diverse voices of women that have historically been ignored, and that this is best accomplished qualitatively, through the interpretation of women's personal narratives. Ann Oakley (1981) famously argued that feminist research ought to strive for mutuality, especially in terms of reciprocity and respect, and feminist research methods thus developed to favour informal relationships with respondents on a qualitative interviewing basis (Finch 1984; Oakley 1981).

More recent arguments, however, have questioned the assumption that by virtue of a shared gender between interviewer and interviewee, rapport and a 'level playing field' are necessarily possible. Anti-essentialist theorists argue that feminist research must acknowledge other differences between women, claiming that there is no single, unique women's experience (Barrett 1980; Butler 1990; Fraser and Nicholson 1990). Cotterill (1992) argues that to presume 'sisterhood' neglects other social factors such as race, class and age, and though the collective category of women is of course useful, it is important to acknowledge divisions that cut across gender and the fact that researchers cannot 
automatically 'reach' participants simply because of a shared gender. Stanley and Wise (1990) suggest that the category 'women' needs deconstructing and appreciating in its complex and differentiated forms. Cotterill (1992) also claims that it is impossible to create a completely non-hierarchical relationship between interviewer and interviewee and that the interview is a fluid process in which balances of power and control shift throughout. It is therefore necessary for feminist research to acknowledge the subjective and intersubjective dimensions of the research, which inevitably impact upon the research process in numerous ways.

Black feminist critics of the notion of 'sisterly' research question the privileging of gender over race and ethnicity (see Crenshaw 1995) and argue for an intersectional approach, which considers overlapping social factors in the formation of power and positionality. Intersectional approaches also critically reflect on the historical, economic and social context of the research and its participants. In the case of this research, interview dynamics were firmly structural and hierarchical in terms of resource and power along intersecting axes of ethnicity, age, class, caste and gender.

The ways in which the fieldwork unfolded were sometimes undeniably counter to the feminist aim to foreground the wellbeing and dignity of women participants. For example, upon our arrival at the Rojiroti field office in the rural village of Shahar Rampur, Bihar, we were introduced to three members of staff at CPSL, all of whom were local men. We were shown logbooks and other documents giving details of loans, including amounts, terms, interest rates and payment conditions. Since preliminary access negotiations were out of our hands, we made repeated overtures (during the initial meeting and on subsequent occasions) to discuss with the men the intricacies of power relations at play when researching marginalised women in the Global South. Our requests were never meaningfully acknowledged and there was a concern on our part that ethical access was compromised, 
insofar as it was not entirely clear that the women had been fully briefed about the option to refuse, a sense that grew as we witnessed women being ushered into interview space by male CPSL staff, on one occasion being abruptly ordered where to sit. These men assumed their own inclusion in focus groups and it was necessary to ask them to leave. One CPSL staff member informed us that the women were 'fighting over being interviewed', and that the women were bound to be empowered through the interview process, suggesting, perhaps, that those with favourable and positive accounts of Rojiroti were constituting the sample and that uncritical epistemological assumptions were therefore being made. These twin factors somewhat undermined the feminist underpinnings of the project, whose methods and methodology set out to shine helpful light on a socially and economically oppressed group, and not to reinforce positivist assumptions about them made from a male vantage point.

Aside from gendered ones, further troubling power asymmetries underpinned field encounters. Ojha and Mini occupied significantly elevated positions of status in relation to the participants in terms of caste and class, and Bott, being the sole white member of the fieldwork team, was problematically positioned in the research in many ways. Her embodied presence was disruptive insofar as she was probably the first white person ever encountered by many or most of the participants. In particular, her light blond hair elicited much curiosity and occasionally terror among village children. This embodied Otherness was of course also highly political, charged with neo-colonial undertones, and imbued with such a lack of 'insiderness' that the appropriateness of her presence in the field is questionable.

Given these problematic factors, the research had, from the outset, aimed to employ a highly reflexive approach from inception, throughout fieldwork to analysis. This includes a critical interrogation of the intersubjective power relations between us, the researchers, and our interlocutors. We had reflected in detail on the considerable class, caste and racial/national power discrepancies underpinning relationships between the interview trio and 
the participants, but we had not anticipated the presence of male CPSL staff in the field. Reflexivity in research is a deconstructive exercise which should, in the words of Macbeth, lead the analyst to 'take up the knots of place and biography' and to 'deconstruct the dualities of power and antipower, hegemony and resistance' (Macbeth 2007: 38) implicit within subjective representations of the social world. The reflexive researcher actively constructs interpretations of the apparent 'facts' of the research, whilst bearing in mind questions about how those interpretations came about (Hertz 1997).

Starting from the premise that all qualitative research—but especially that which involves participant observation and in-depth interviewing techniques_carries potential for harm to research subjects, Guillemin and Gillam (2004) argue that procedural ethical measures such as ethics committees alone are not enough to protect research participants. Research in practice often presents researchers with unexpected 'critical incidents', which necessitate a reflexive and dynamic approach to taking care of participants - what Guilemin and Gillam have termed an 'ethics in practice' approach (2004: 268). Such incidents or 'ethically important moments' may require researchers to make difficult decisions quickly and independently.

Accordingly, the interview team held an urgent meeting to discuss the issue of potentially compromised informed consent and the unwanted presence of male CPSL staff. We revisited our participant information sheet (which was read out in advance of interviews and focus groups), placing greater emphasis on the non-obligatory nature of the research and its aims to better understand Rojiroti and microfinance in all its complexity.

Further, we acted to deliberately exclude our male co-researchers and CPSL staff from interviews and focus groups in order to help nurture a non-patriarchal environment and a greater sense of anonymity and privacy for the women. Since interviews were mainly 
conducted outdoors owing to the lack of indoor community space, we were also tasked with excluding male relatives (and sometimes mothers-in-law) of the women.

It is beyond the scope of this article to fully unpick and resolve the problematic and complex nature of fieldwork that is funded by British research councils, led by a white British academic, set in a postcolonial context, and investigating the situation of some of India's poorest women. It is, however, important to acknowledge the power discrepancies at play, especially in terms of potential compromises to informed consent as a result of power imbalance. Since the research constitutes a pilot study for potential future collaborative research, many important lessons have been learned and will inform subsequent research design.

\section{Rojiroti and Family Dynamics}

Fieldwork yielded basic information on spending, as well as more nuanced themes around benefits and changes brought about by taking out Rojiroti microfinance, including greater levels of independence, freedom and financial security. Negative aspects were also discussed, and these include ongoing indebtedness and feelings of exclusion where it has not been possible for women to join a SHG. We return to each of these areas in detail below.

\section{Basic Spending Patterns}

Our initial task was to ask participants to tell us how their loans were spent. Interviews revealed that medical treatment for themselves or a family member was the most common expenditure, followed by agricultural material including seeds, share-cropping fees and other materials: 


\begin{tabular}{|c|c|}
\hline Items Purchased with loan(s) & Frequency \\
\hline Medical treatment & 19 \\
\hline Agriculture/share-cropping & 12 \\
\hline Education (of children) & 9 \\
\hline $\begin{array}{l}\text { Livestock/animal husbandry } \\
\text { (including cattle sharing) }\end{array}$ & 7 \\
\hline Delivery of baby & 6 \\
\hline Fresh food & 4 \\
\hline $\begin{array}{l}\text { Wedding/dowry (of } \\
\text { daughter/sister) }\end{array}$ & 4 \\
\hline Milk & 4 \\
\hline Construction/home improvements & 4 \\
\hline Pay prior debts & 3 \\
\hline Small business (shop) & 3 \\
\hline Attend a wedding & 2 \\
\hline Clothing for children & 1 \\
\hline Rations & 1 \\
\hline
\end{tabular}

Table 2 showing items purchased with loans (data drawn from interviews only to avoid reproduction of frequency).

\section{Healthcare: No Strings Attached}

The figures above are useful pointers towards understanding links to improved children's health. Despite attempts to establish an adequate department of public health, including the introduction of the National Rural Health Mission, chronic under-investment in government health provision has led to significant weakening of the systems and has 'crippled Bihar's ability to deliver good quality health care' (Mukhopadhyay 2012: N.P.). Poor state provision 
leads to reliance on private medical care and the ratio of private spending on health care relative to public spending in Bihar is the second highest in India (Berman et al 2017). This places the burden of healthcare costs, including transportation to and from hospital and paying for natal care, directly on families. Rojiroti loans are frequently used to meet these costs, as explained in the interview quotes below:

'We go to private clinic in block headquarters. Government hospitals do not have good facilities and it is also very crowded' (FG 1, Rojiroti loan recipient for more than 2 years).

'Yes, their [interviewee's children] health is definitely getting better. Earlier I have taken 5000/- rupees from 'Mahajan' [private, independent money-lender] but I had to pay back Rs. 20,000/- with exorbitant rate of interest. In (NGO ANONYMISED) [Rojiroti] we can repay in small instalments as per my convenience and rate of interest is also lower. It has helped us to increase our family income which impacted the health in positive manner' (Interviewee 2, Rojiroti loan recipient for 10 years).

Interviewee 2 explains the preferential terms offered by Rojiroti with regard to interest rates and repayment schedules, which make the loans manageable. This means that medical emergencies can be paid for with Rojiroti money in a prompt and comparatively worry-free way. These thoughts were echoed by another long-term Rojiroti member: 
'This is very beneficial for us. We can always take loans for our needs.

Now the loan amount has also increased as the group has become bigger.

It is also good for savings. We had to go to 'Mahajan' [private moneylender] for loans and pay up to 10 percent interest rate. We have to work in the Mahajan's fields without payment. They can ask anytime, to work for them without paying and wages and we have to do it' (FG 1: Rojiroti loan recipient for more than 5 years).

In addition to providing necessary funds to access private healthcare, Rojiroti microfinance gives women freedom to prioritise their own family needs, and to collectively grow their SHG in ways they see fit. This is in contrast to Mahajan loans, which are individually allocated and come with high interest rates and unmanageable conditions including debtbonded labour. This restricts borrowing levels and can force women to undertake unplanned work in lieu of payment. Such insecurity and conditionalities are both worrying and disempowering. Zelizer discusses how conditions, or 'strings attached' affect the quality of money and the social dynamics surrounding it. The ways that different debts (e.g. NGO versus private) are earmarked are contingent on the creditor/recipient relation. As Zelizer suggests, it is necessary to 'differentiate between top-down forms of monetary earmarking, such as those instituted by the state or other powerful agencies and bottom-up differentiations created by people's everyday relations' (Zelizer 2012: 163). The women's own 'bottom-up' earmarking of loan money is important as the lack of imposed conditions on Rojiroti credit imbues the money with meanings of independence and freedom. 
Safeguarding for Food Supply Longevity

Perhaps surprisingly, immediate spending of loans on food was reported by only four of the 19 interviewees. Many more members (12 of 19) used loan money to make ongoing agricultural investments, which lead to longer-term food security:

'We have taken loan for education of child and also for cropping. Our family do agricultural work and we crop flowers. I have taken 200 rupees as loan and cropped flowers in one kattha field. After selling the flowers we found that it is beneficial for us. After paying the loan amount again I took it and cropped flowers in 2 kattha field. In this way our income has increased' (FG1 Rojiroti loan recipient for more than 5 years).

'I have taken loans about ten times. First time, I took it for buying a cow. We use its milk for the consumption of family members and also sell it in village market. Every year I take loan for agriculture from Rojiroti' (FG 1 Rojiroti loan recipient for 5 years).

Again, the quotes show that borrowers safeguard loan monies to suit the needs of their own families, including investing in food sources. Such decisions, which are self-directed, gainful, and borne of experience and know-how are communally beneficial and there is a suggestion that negotiations around safeguarding money for food-related investments help define family and community dynamics (Wilkis, 2017).

Indeed, decision-making in the home was frequently mentioned in focus groups and interviews. Discussions predominantly revealed harmonious and mutual financial negotiations around microfinance, with many women stating that their husbands worked with 
them to provide repayments. Data revealed improved family relations and heightened independence gained by some Rojiroti members:

'Initially, I was not permitted to go outside from home and did not have much knowledge about the scheme. Then I met someone who runs the group. I learned how to run the group and details about Rojiroti programme. Later, I got a chance to start and lead a Rojiroti group in this tola. I belong to a very poor family. It was very tough to give good education to our children. But this scheme gives us small loans which have benefitted us a lot. I took loan for agricultural purpose as well. We consume most of the farm produce, grown in our field, in the family and also save some for seeds for next season. Second time I took loan for constructing our house. I also use loan for educating my daughter' (FG 2, Rojiroti member for 5 years).

This quote illustrates the enrichment of some members' lives after joining a SHG. From being controlled and confined by relatives to gaining autonomy and freedom through her involvement with Rojiroti, this member describes a positively transformative experience. She explains how this led to access to better food produce, better housing and schooling for her child. These factors all contribute to long-term improvements in health and wellbeing. A similar pattern is described by another participant:

'Before joining the Rojiroti group I was not permitted to go outside the home. I used to face scarcity of money then. After joining the group I am in more comfortable situation and feeling better. I do not ask for money from my in-laws. Whenever my children get sick I can easily take loan and 
provide them better treatment. Earlier I had to ask my in-laws for this and they did not care about it. I take very small loan also. Whenever my children get sick, I take Rs 100/- or 200/- and go to the doctor for their treatment. Now my children are getting better food. This scheme is also very good for saving' (Interviewee 10, Rojiroti member for 5 years).

There are suggestions here that loans provide an arena for the negotiation of power in immediate and extended family, with the safeguarding of money acting to secure women's discretion and family/group solidarity. In the following quote, Interviewee 6, a 35-year-old mother of two, also described past intimate partner violence (IPV) from her husband but explained that this stopped when she took out a loan:

'With mutual agreement [with husband] and as per the need of the family, I take loan and husband repays it. Without his permission how can I take the loan? Both of us decide according to the situation. Now I take all the decisions regarding the loan or any other important issues of the family. My husband and even my in-laws gave freedom to take decisions on behalf of the family' (Interviewee 6, Rojiroti member for 3 years).

IPV was reported by five women, three of whom felt that Rojiroti loans had helped their situation in this regard. 
Exclusion and Prevention from SHG Membership

Not all women, however, started from a position of having the permission of their husbands to join a SHG. For example, a younger interviewee, aged 24 with two children, wanted to take out a Rojiroti loan but was prohibited from doing so by her husband, under conditions of violent coercive control:

'He is very different and suspects everything including my activities. He does not want that I should involve in anything and does not feel it is beneficial. I do not know much about this and also did not talk about the scheme with any other women. I usually remain in my house and do not talk much with other women. But I guess when other women have joined the scheme it must be a good scheme... I have not joined the scheme and every woman in the tola has joined it. It is obvious that I feel excluded sometimes' (Interviewee 4, non- member despite availability in her tola).

This interviewee led a particularly isolated life in her tola and stated that she was one of the poorest women there. Her husband is an alcoholic who subjects her to frequent beatings. Another interviewee, aged 50 and mother to four adult children, told us her husband had left her and that she was solely responsible for the household income. Therefore, she did not feel secure enough to join a loan group:

'No, how can I take loans, there is no one in my family who can pay the loan. I live alone in my house and earn livelihood on my own through agriculture labour. It will be tough for me to repay the loan and interest'. 
Interviewer: 'Do you want to join Rojiroti?

'Yes, I wish I could join it, but I do not have regular income and moreover I do not anyone who can repay the loan amount on my behalf' (Interviewee 9, non- member despite availability in her tola).

These examples show that exclusion from Rojiroti SHGs can be isolating for women in the least advantageous positions. Exclusion can also occur when membership is refused by a SHG leader and/or other members:

\author{
'At the time of formation of group, I was staying in Patna. Later I came to \\ tola and got to know about the scheme. I requested the group leader to \\ include me. But members told that they cannot include me now. I want to \\ join it' (Interviewee 8, non-member despite availability in her tola).
}

This quote suggests that such SHG exclusion can be divisive and painful. With the emphasis on networks and group cohesion, it follows that exclusion can be dispossessing, both financially and socially. Relational benefits of earmarking and safeguarding are therefore contingent on owning a certain level of relational status and autonomy to begin with and are thus not accessible for the most marginalised members of the community. This illustrates how power relations between women of similar caste positions are varied and potentially further complicated by microfinance (Guérin 2011). 
Divisions Created by Unavailability of Rojiroti

As a small and financially limited organisation, CPSL is not always able to meet demand to form new groups, and we encountered a degree of frustration about the lack of availability of Rojiroti in one remote tola. In tolas outside the geographical reach of Rojiroti and where other NGO microfinance is unavailable, there is an overall sense that Rojiroti is wanted and needed to provide relief from poverty and Mahajans (private moneylenders):

\begin{abstract}
'I cannot afford expensive treatment from private facilities. It is the main reason I cannot take complete treatment. In emergency situations, I take loan from 'Mahajan' and pay him ten percent interest rate per month'...
\end{abstract}

\title{
Interviewer: 'Do you think loan schemes like Rojiroti can improve condition of your family'?
}

'Yes, it can give us big relief from 'Mahajans'. We have to pay ten percent per month as interest rate. But the schemes which have very low interest rate, will definitely be very useful for us...

[Health] is not very good. I also have cattle, so I and my family members get milk or milk products regularly. My husband is a daily wage labourer. Our income is very low and hence we cannot afford costly food items from the market, such as, fruits, vegetables, etc' (Interviewee 10, non-member as Rojiroti not available in tola).

These quotes support the idea that private borrowing presents more problems than it solves and is viewed as a dangerous last resort for dealing with medical emergencies. Rojiroti, on the other hand, is chiefly seen as a safer option. One young woman from the same sample 
group, however, strongly objected to microfinance and the burden of debt it placed on women:

'We do not want Rojiroti; we do not want debt... Taking loan from any source is not good. We have to pay back the loan with interest which is a big burden for us' (Interviewee 17, elective non-recipient).

This is a minority voice, yet it provides an important counter-narrative to the predominantly positive evaluations of Rojiroti encountered in the study and illustrates an awareness of the problem of ongoing indebtedness created by microfinance of any sort.

\section{Conclusions}

Despite India being one of the fastest-growing economies in the world, with overall poverty reduction and improved health, poor women and children often do not benefit from development and remain trapped in poverty and precarity (Duflo, 2012). In the absence of adequate state provision and secure work, India's poorest women narrowly survive on multiple unreliable incomes, meaning they cannot take the risks associated with other forms of credit provision that carry penalties for non-payment. Rojiroti microfinance aims to alleviate women's poverty with minimal debt burden and impositions/conditions, which makes Rojiroti and other such NGO schemes preferable to most women.

The communities studied in this research are among the poorest and most marginalised women in India. Microfinance is often promoted as an empowering route out of poverty, mainly through microenterprise, yet studies have shown that meaningful enterprise is not a common outcome of microcredit but that more immediate needs such as food are met 
through borrowing (Karlan and Zinman 2010; Banerjee et al 2013). Buying food potentiates better children's nutritional health, as does investment in healthcare and cropping, which emerged as the main items purchased by the women in this study.

Rojiroti finance is exclusively available to women and is therefore earmarked for the specific purpose of advancing women's welfare and status in a patriarchal setting. Just as money gained through dubious means such as by deception or stigmatised labour can be considered 'dirty money' (Carruthers, 2010: 61), monies earmarked for the benefits of women are positively evaluated, leading to more mutual and even power relations in families. Rojiroti comes with very few stipulations, which allows for autonomous planning and management of household finances by women. This is generally accepted in extended and inlaw families, which appears to enhance women's status in the home, sometimes leading to lower rates of IPV. The combination of higher status and autonomy in families, better access to health services and cohesive and strategic investments in food sources appears to lead to the improved health of children.

However, interviews have shown that where Rojiroti is not available, women can feel excluded and further marginalised by their inability to join a SHG. This constitutes exclusion from valuable group cohesion and mobilisation that can earn elevated social standing (Sultana, 1998) and in turn can exclude women from the potential to speak out and take control of family finances. There is also a small but audible voice of resistance to Rojiroti and other schemes because of the state of indebtedness in which microfinance places families, and the prospect of any type of debt deters some women from joining.

Debates in microfinance are conflicting and empirical research shows a wide range of benefits and drawbacks for women and families. By considering the social and familial meanings of SHG microfinance for the first time, we can argue that the nonpecuniary value 
and meanings of microcredit are of most significance to women's changing roles and experiences. Currencies including agency and power, which manifest in decisions about how to spend money allocated to mothers can lead to improved health and wellbeing of their children. Rojiroti money is safeguarded and earmarked by mothers for expenditures they themselves identify as beneficial to family health, whether in consultation with husbands and other family members or more independently. The money is thus used to redefine and sustain social relations in ways that elevate the standing of members. SHG membership connects women to one another through group meetings, but also to the debt itself, which, in macrofinance and indeed many other forms of microfinance, is an abstract, anonymous relationship between borrower and creditor. In SHG borrowing, the economic transaction is morally bound (Polletta and Tufail, 2014) by requirements of the communal SHG relationship. Safeguarding repayments becomes a manageable moral duty, which is helped along by the favourable terms and conditions of the Rojiroti scheme. This in turn helps women to adhere to sustainable long-term budgets to provide food security and healthcare for their children. 


\section{References}

Banerjee, A. V.; Duflo, E.; Glennerster, R.; Kinnan, C. (2013) The Miracle of Microfinance? Evidence from a Randomized Evaluation. MIT Department of Economics Working Paper No. 13-09. Available at: https://ssrn.com/abstract=2250500

Barrett, M. (1980). Women's Oppression Today: The Marxist / Feminist Encounter. New York: Verso.

Berman, P; Bhawalkar, M; Jha, R (2017). "Tracking financial resources for primary health care in BIHAR, India. A report of the Resource Tracking and Management Project" (PDF). Harvard T.H. Chan School of Public Health. Archived (PDF) from the original on 20 July 2018. Retrieved 20 July 2018.

Butler, J. (1990). Gender Trouble: Feminism and the Subversion of Identity. London and New York: Routledge.

Carruthers, B. G. (2010) 'The Meanings of Money: A Sociological Perspective', Theoretical Inquiries in Law 11 (1) pp. 51-74.

Cotterill, P. (1992). Interviewing Women: Issues of Friendship, Vulnerability and Power. In: Women's Studies International Forum. 15 (5/6). pp 593-606.

Crenshaw K.W. (1995) 'Mapping the Margins: Intersectionality, Identity Politics, and Violence Against Women of Color,' in K.W. Crenshaw, N. Gotanda, G. Peller and K. Thomas (eds) Critical Race Theory: The Key Writings that Formed the Movement (New York: The New Press).

Cyr, J. (2016) The pitfalls and promise of focus groups as a data collection method. Sociological Methods \& Research, 45 (2) 231-259.

Duflo, E. 2012. "Women, Empowerment and Economic Development.” Journal of Economic Literature 50 (4): 1051-1079.

Finch, J. (1984). It's Great to have Someone to Talk to: The Ethics and Politics of Interviewing Women. In: Bell, C. and Roberts, H. (eds). Social Researching: Politics, Problems and Practice. London: Routledge and Kegan Paul.

Fraser, N., and Nicholson, L. (1990). Social Criticism without Philosophy: An Encounter between Feminism and Postmodernism. In: Nicholson, L. (ed). Feminism/Postmodernism. New York: Routledge. pp. 19-38. 
Goetz, A.M. and R. Sen Gupta 1996, 'Who takes the credit? Gender, power, and control over loan use in rural credit programmes in Bangladesh', World Development, 24(1), 4563.

Gopinath, V. (2018) 'Who are the Scheduled Castes, Scheduled Tribes, OBCs and EBCs? The Quint, found at: https://www.thequint.com/explainers/scheduled-caste-scheduledtribe-obc-ebc-sc-st-prevention-of-atrocities-act-explainer. Accessed 29/01/20.

Guérin, I. (2011). 'The Unexpected Consequences of Microfinance'. Travail Genre et Societes (1), 61-79.

Guérin, I.; Kumar, S. \& Agier, I. (2013) Women's Empowerment: Power to Act or Power over Other Women? Lessons from Indian Microfinance, Oxford Development Studies, 41:sup1, S76-S94, DOI: 10.1080/13600818.2013.781147

Guérin, I. and Palier, J., eds. 2005. Microfinance Challenges: Empowerment or Disempowerment of the Poor?, Pondicherry (India): IFP. Coll. Sciences Sociales $\mathrm{N}^{\circ} 10$

Guillemin, M. and Gillam, L. (2004) 'Ethics, Reflexivity, and "Ethically Important Moments" in Research' Qualitative Inquiry, 10: 261- 280.

Harding, S. 1987. Introduction: Is there a Feminist Method? In: Harding, S. (ed). Feminism and Methodology. Milton Keynes: Open University Press. pp 1-14.

Hashemi, S., Schuler, S. and Riley, A. 1996. Rural credit programs and women's empowerment in Bangladesh. World Development, 24(4): 635-654.

Hulme, D. and Arun, T. (2011) 'What's Wrong and Right with Microfinance.' Economic \& Political Weekly 46.48: 23-26.

Hunt, J and N. Kasynathan (2001) Pathways to empowerment? Reflections on microfinance and transformation in gender relations in South Asia, Gender and Development, 9 (1) pp. 42-52.

Karim, L. (2011) Microfinance and its Discontents: Women in Debt in Bangladesh, University of Minnesota Press. 
Karlan, D. and Zinman, J. (2010) 'Expanding Credit Access: Using Randomized Supply Decisions to Estimate the Impacts in Manila', Review of Financial Studies 23(1): 433464.

Kumar, V., Chauhan, M., \& Kumar, R. (2015) 'An Overview Of Microfinance In India', Abhinav-National Monthly Refereed Journal Of Research In Commerce \& Management, 4(10), 19-26.

Mader, P. (2015) 'The financialisation of poverty', in Mader, P. The political economy of microfinance: financializing poverty, Basingstoke: Palgrave Macmillan, pp. 78-120.

Mukhopadhyay, I. (2012) 'Health system strengthening and the importance of Public investment: A study of National Rural Health Mission in Bihar', BMC Proceedings, 6(5), 1-2. Retrieved 09/08/19, from https://bmcproc.biomedcentral.com/articles/10.1186/1753-6561-6-s5-o11.

Oakley, A. (1981) 'Interviewing Women: A Contradiction in Terms', in: Roberts, H. (ed). Doing Feminist Research. London: Routledge and Kegan Paul. 30-61.

Pattenden, J. 2010 'A neo-liberalisation of civil society? Self-help groups and the labouring class poor in rural south-India'. Journal of Peasant Studies, 37(3): 485-512.

Pitt, M. \& Khandker, S. R. (1996) Household and Intra-household Impacts of the Grameen Bank and Similar Targeted Credit Programs in Bangladesh, World Bank Discussion Papers 320, Washington, DC

Polletta, F., \& Tufail, Z. (2014). The Moral Obligations of Some Debts. Sociological Forum, 29(1), 1-28. Retrieved November 10, 2020, from http://www.jstor.org/stable/43653930.

Rankin, K. N. 2002. Social capital, microfinance and the politics of development. Feminist Economics, 8(1): 1-24.

Shettar, R. (2015) 'A Study on Issues and Challenges of Women Empowerment in India' IOSR Journal of Business and Management (IOSR-JBM) e-ISSN: 2278-487X, pISSN: 2319-7668. Volume 17, Issue 4.Ver. I PP 13-19.

SIDBI (2019) Microfinance Pulse Report: Vision of Microfinance in India, available at: https://www.sidbi.in/en/microfinance-pulse 
Sinha, S. K., \& Agarwal, P. K. (2010). Disclosure and Financial Performance: A Crosssectional Study of Microfinance Institutions of India. Review of Professional Management- A Journal of New Delhi Institute of Management, 8(1), 20-30.

Stanley, L. and Wise, S. (1990) 'Method, methodology and epistemology in feminist research processes', in Stanley, L. (ed). Feminist Praxis: Research, Theory and Epistemology in Feminist Sociology. London: Routledge. pp.20-60.

Verma, S., \& Aggarwal, K. (2014). Financial Inclusion through Microfinance Institutions in India. International Journal of Innovative Research and Development, 3(1).

Vijayanthi, K. N. (2003). Womens empowerment through self help groups a case study of urban community development programme. Retrieved 30/08/19 from http://shodhganga.inflibnet.ac.in:8080/jspui/handle/10603/85869

Wilkis, A. (2017) The Moral Power of Money: Morality and Economy in the Life of the Poor, Stanford University Press.

Zelizer, V. A. (1997) The Social Meanings of Money: Pin Money, Paychecks, Poor Relief, and Other Currencies, Princeton: Princeton University Press.

Zelizer, V. A. (1989) 'The Social Meaning of Money: "Special Monies"', American Journal of Sociology, Vol. 95, No. 2, pp. 342-377 (36 pages)

Zelizer, V. A. 2012. "How I Became a Relational Economic Sociologist and What Does That Mean?" Politics \& Society 40: 2: 145-17

Yaron, G., Gordon, R., Best, J., \& Choudhary, S. (2018). Microfinance for the marginalized: the impact of the Rojiroti approach in India. Enterprise Development and Microfinance, 29(1), 80-93.

Yaron, G., Gordon, R., Best, J., \& Choudhary, S. (2019) Challenging the links between microfinance and domestic violence: evidence from rural India, Development in Practice, DOI: $\underline{10.1080 / 09614524.2019 .1696282}$

Ojha, S., Szatkowski, L., Sinha, R., Yaron, G., Fogarty, A., Allen, S. J., Choudhary, S., Smyth, A. R. (2019) Rojiroti microfinance and child nutrition: a cluster randomised trial. Arch Dis Child.: http://dx.doi.org/10.1136/archdischild-2018-316471 
